\title{
Strach z lesa: vliv programu environmentální výchovy na snižování obav žáků z pobytu v lesním prostředí
}

\author{
Jan Činčera \\ Envigogika 2012/VII/2- Recenzované články/ Reviewed Papers \\ Publikováno/Published 30. 09. 2012 \\ DOI: http://dx.doi.org/10.14712/18023061.74
}

\begin{abstract}
Abstrakt:
Článek prezentuje výsledky analýzy programu "Les ve škole - škola v lese" pro šestý ročník základních škol. Cílem bylo zjistit, čeho se děti v lese bojí a zda je program úspěšný ve snaze obavy dětí z lesa zmírnit. Evaluace využivala jednoduchý evaluační plán typu pretest/posttest $(\mathrm{N}=70)$. Podle výsledků lze ríct, že děti chodí do lesa poměrně málo, chlapci častěji než dívky. Celkově lze říct, že se děti lesa moc nebojí, dívky se ale bojí lesa více než chlapci. Děti mají strach zejména z prírodních hrozeb, jako je ohrožení divokou zvěří, a sociálních nebezpečí, tj. ohrožení zlými lidmi či nehodami způsobenými lidmi. Zdá se, že program neměl př́liš velký vliv na chlapce, ale pravděpodobně zapůsobil na dívky, u kterých bylo naměřeno snížení hladiny obav ve všech třech hlavních oblastech (prírodní ohrožení, sociální ohrožení, nepř́ijemné situace).
\end{abstract}

\section{Klíčová slova:}

Strach z lesa, evaluace programu

\begin{abstract}
:
The article presents results of an analysis of the program "Forest at school - school in the forest", for 6th grades' pupils. The aim of this work was to investigate the sources of fear of forest and the effectiveness of the program in its effort to deal with it. The evaluation applied a simple pretest/posttest design $(\mathrm{N}=70)$. On the basis of its results we can presume that pupils visit forests quite rarely; boys more often than girls. Generally, children are not scared of a forest; girls are more scared than boys. Children mainly fear natural threats (e.g. wild animals); and social risks, e.g. threat from bad people or humancaused accidents. The program probably did not have much effect on boys but probably influenced girls where the level of fear in all the areas of sources of forest fear (natural threats, social threats and uneasy situations) decreased.
\end{abstract}

\section{Key words:}

Fear of forest, program evaluation 


\section{Úvod}

Podle Richarda Louva (2008) roste v moderní společnosti strach z volné přírody. Kvůli strachu nechtějí rodiče pouštět děti ven, přestože nedostatek kontaktu s přírodou mưže znamenat újmu pro jejich psychický i fyzický vývoj.

Bojí se ale přírody samotné děti? Pokud ano, čeho? Je možné jejich strach zmírnit pomocí programu environmentální výchovy?

Strach z přírody je předmětem řady výzkumných studií. Velká skupina výzkumníků spojuje strach z přírody s evolučně-biologickými důvody. Podle nich se bojíme fenoménů, které pro lidstvo dříve znamenaly ohrožení a jejichž rysy jsou v nás geneticky zakotvené. Těmi jsou bud' jednotlivé přírodní objekty, jako jsou hadi či pavouci, nebo určité krajinné charakteristiky (Berg a Heijne, 2005). Andrews a Gatersleben (2010) např́klad vycházejí z teorie, podle které lidé evolučně preferují krajinu, která je přehledná, je v ní málo míst, na kterých se mohou schovat prípadní útočníci, a lze z ní v případě ohrožení snadno utéct. Podle jejich výzkumu respondenti cítí v málo přehledné krajině větší nebezpečí a spojují ji $s$ většími obavami. Krajina $s$ malou přehledností byla také méně preferována než krajina se střední či nejvyšší přehledností.

K obdobným závěrům dochází i další autoři. Podle Herzoga a Kutzli (2002) jsou klíčovými faktory pro preferenci určité krajiny její přehlednost a pěší dostupnost, obě kategorie současně negativně korelují s pocitovaným nebezpečím z krajiny. Herzog a Kropscott (2004) v návaznosti na Kaplanovu teorii atraktivity krajiny (in Stibral a Stella, 2009) dále uvádí čitelnost a koherenci krajiny, tedy distribuci a uspořádanost prvkứ v př́rodě, které nám umožní se $v$ ní dobře orientovat. Pro zajištění čitelnosti krajiny pak jsou zásadní př́tomnost krajinných znaků a dobrá přehlednost krajiny. Pro pocit klidu a pohody pak lidé preferují otevřenou přírodní krajinu, negativním faktorem je naopak množství vegetace a listí na povrchu (Herzog a Chernick, 2000).

Mezi preferencí určité krajiny, pocitem nebezpečí a strachem z krajiny současně nejsou jednoznačné vazby. Preference a nebezpečí sice spolu negativně korelují, nejsou ale svými vzájemnými opaky. Zatímco pocit nebezpečí souvisí s kognitivním porozuměním situace a mưže být respondenty vnímán i pozitivně ( $v$. adrenalinové sporty), strach je spojován s negativními emocemi (Andrews a Gatersleben, 2010). Podle Herzoga a Kutzli (2002) mưže být nebezpečí vnímáno jako atraktivní. Nebezpečí a strach spolu korelují, ale ne vždy vede pocit nebezpečí ke strachu. Podle Kaplana (in Herzoga a Kutzli, 2002; Herzog a Kropscott, 2004) představuje určité propojení mezi pocitovaným nebezpečím a současně preferencí určité krajiny pocit tajemství spojovaný s krajinou. Podle Herzoga a Kropscotta (2004) se ale tuto domněnku nepodařilo prokázat.

S teorií vysvětlující strach z přírody typem krajiny naopak nesouhlasí Berg a Heijne (2005). Podle nich strach z přírody není spjatý s prostorovým kontextem divočiny, ale může se objevit $v$ jakémkoliv typu prostředí a je evokován relativně běžnými podněty, jako je př́tomnost zvířat, tma, samota nebo přírodní síly (bouřka atd.). Pocit ohrožení pak může souviset i s pozitivními emocemi, jako je štěstí, fascinace či úžas. Jedněmi respondenty mohou být stejné situace zažívány jako ohrožující, jinými jako zábavné a pozitivní. Př́čina strachu tedy neleží $v$ univerzální reakci člověka na stejné druhy podnětů, ale $v$ individualitě návštěvníků přírody. Rozdíly je možné najít $v$ genderu $a v$ typu návštěvníků. Při hodnocení stejných podnětů jsou muži a turisté, kteři $v$ přírodě vyhledávají adrenalinové vzrušení, častěji potenciálně ohrožujícími prírodními jevy fascinováni než vystrašeni.

Individuálnost prožívání přírody zdůrazňuje i Skårová (2010). Podle ní je zkušenost přírody dynamická, situační a kulturně konstruovaná. Například to, že ženy mají z pobytu v přírodě větší strach než muži, Ize vysvětlit sociálními příčinami: vlivem rodiny, médií. Stejný les může být různými respondenty interpretován rozdílně, mohou si ho spojovat $\mathrm{s}$ různými emocemi, které se mohou $v$ průběhu času změnit. Zásadním faktorem 
ovlivňujícím vztah k lesu pak je zkušenost: „....jediný způsob, jak změnit negativní vztah k lesu na pozitivní je prostřednictvím pozitivních, komplexních zážitků v lesním prostředí." (p. 115)

Andrews a Gatersleben (2010) zkoumali tři typy ohrožení, které lidé v lese zažívají: fyzické ohrožení spojené například s útokem divokých zviŕat, sociální ohrožení, kdy potenciálním agresorem jsou lidé a nebezpečí ztracení se $v$ přírodě. Zatímco u sociálního ohrožení nehrál charakter krajiny roli, $v$ méně přehledné krajině rostl pocit fyzického ohrožení a obav ze ztracení se v prírodě.

Situace u dětských respondentů je analogická. Přestože vztah dětí k př́rodě je na obecné rovině pozitivní a empatický, děti současně cítí $v$ př́rodě ohrožení ze strany zlých lidí, divokých zviŕat či ztracení se v terénu (Rickinson, 2001; Emmons, 2011).

Vztah dětí $\mathrm{k}$ lesu byl $v$ České republice zkoumán $v$ evaluaci zpracované jako součást analýzy potřeb pro programu Sdružení TEREZA Les ve škole - škola $v$ lese (Činčera, 2012a). Podle ní chodí děti do lesa rády, současně přiliš nerozumí tomu, jak les funguje. Předkládaná studie na tento výzkum navazuje a zaměřuje se specificky na zdroje strachu dětí z lesa.

\section{Popis programu}

Program Les ve škole - škola v lese prochází od roku 2012 rozsáhlou modifikací. Program je určen pro žáky základních škol, přičemž každý ročník má svůj specifický program, zaměřený na určité téma a výchovně-vzdělávací cíle. Hlavním cílem programu pro šestý ročník je, aby žáci vnímali les jako bezpečný, svobodný prostor, ke kterému si vytváří osobní vztah (Danišová, 2011).

$\checkmark$ rámci jednotlivých aktivit se program snaží jednak rozvíjet u dětí pozitivní motivaci k návštěvě lesa, jednak zmírnit jejich zdroje ohrožení a obav z lesa. Zdroji ohrožení, kterými se program zabývá, jsou zviřata (klíśtata, bodavý hmyz, divoká prasata, vlci, medvědi) a podmínky (špatné počasí, těžký terén). Zdroje ohrožení a obav jsou $\checkmark$ programu jednak racionalizovány (např. poukázáním na malý počet případů napadení člověka šelmami $v$ českých lesích), jednak se program snaží rozvíjet kompetence pro prevenci vzniku ohrožení (např. jak si sbalit věci, jak se chránit před klíštaty).

Program dále rozvíjí kompetence pro atraktivní trávení volného času $v$ prírodě. Jednotlivé aktivity motivují $\mathrm{k}$ hrám $v$ př́rodě (např. geocaching, land art), sběru lesních plodů, naplánování výletu do přírody a prožitku samoty v prírodě (nalezení si svého místa).

Program vedou na jednotlivých školách učitelé s pomocí pracovních listů dodaných Sdružením TEREZA. Předpokládaná délka programu je tři až šest měsíců.

\section{Metodika evaluace}

Cílem evaluace bylo odpovědět na následující otázky:

- Čeho se děti v lese bojí? Existují rozdíly mezi chlapci a dívkami?

- Změnila se v průběhu trvání programu míra strachu dětí z lesa?

V roce 2012 , kdy byl program poprvé testován, se do jeho ověřování zapojilo šest tříd. Data se podařilo získat od čtyř z nich. Celkem se podařilo spárovat 70 respondentů, z toho 42 dívek a 28 chlapců, průměrný věk 11,7 let $(S D=0,8)$.

Každý žák dostal stejný dotazník před zahájením programu a po jeho ukončení. Dotazník obsahoval dvaceti položkovou škálu měřící strach dětí z lesa. Otázky byly 
uvedeny vysvětlujícím komentářem a větou "Když jsem v lese, bojím se...". Jednotlivé položky pak obsahovaly možný zdroj obav dětí v lese (např. klíště, divoká zvířata, že se ztratím, že se ušpiním atd.). Záci zaškrtávali na sedmibodové Likertově škále, která byla vizualizovaná pomocí "smajlíků". V příkladu bylo žákům vysvětleno, že pokud z dané situace nemají strach, mají zaškrtávat usměvavé smajlíky, pokud strach mají, tak zamračené. Smajlíci pak byli kódováni na číselnou osu 1-7, kdy "1" znamená nejmenší strach a "7" největší.

Předvýzkum prokázal dobrou reliabilitu nástroje. To se potvrdilo i v samotném výzkumu, kdy hodnota Cronbach alfa $v$ pretestu byla alfa=0,89 a v posttestu alfa=0,91. Přestože dotazník dobře fungoval jako celek, na základě faktorové analýzy byly $v$ nástroji identifikovány tři podškály.

Podškála „sociální ohrožení" se skládala ze tří položek (Cronbach alfa=0,76): „že mi někdo ubliží", „že mě omylem zastřelí myslivec", „že potkám pytláka". Škála koresponduje se sociálním typem ohrožení, tedy nebezpečí ze strany lidí (Andrews a Gatersleben, 2010).

Podškála "přírodní hrozby" se skládala ze sedmi položek (Cronbach alfa=0,87): "divokých zvířat", „že potkám vlka", „že mě uštkne zmije"," že potkám rozzlobené divoké prase", "že na mě při bouřce spadne strom", "že mě kousne sršeň", "že zapadnu do bažiny". "Škála koresponduje s fyzickým ohrožením podle Andrewse a Gateslebena (2010). Jednotlivé položky zde představují přírodní nebezpečí, která jsou dětmi vnímána jako životně nebezpečná. Oproti původnímu předpokladu s ostatními položkami $v$ této škále nekorespondoval strach z klíštat.

Poslední podškála označuje „nepříjemné situace $v$ přírodě" a skládá se z osmi položek (Cronbach alfa=0,7): "že se ztratím", "že se ušpiním", "že nenajdu cestu domư", "že zmoknu", "že nastydnu", "že ztratím signál mobilu", "že zapadnu do bažiny", "že nebudu vědět, jak se tam mám zabavit". Škála rozšiřuje třetí dimenzi obav, kterou u Andrewse a Gateslebena (2010) byla obava ze ztracení se v př́rodě. Oproti předpokladu s ostatními položkami nekorespondovaly "že šlápnu do něčeho hodně ošklivého" a "že se budu nudit" a nebyly proto do podškály zařazeny. Naopak, položka "že zapadnu do bažiny" korespondovala se dvěma podškálami. Celkově škála obsahuje situace, pro které je typické, že se respondenti nacházejí v situaci, která není nutně smrtelně nebezpečná, ale je určitým způsobem nepř́jemná a její zvládnutí vyžaduje specifické kompetence: orientaci v př́rodě, odhad počasí, dobré vybavení na cestu.

Jako nezávislé proměnné byly vyhodnocovány pohlaví a četnost návštěv lesa za poslední měsíc, kdy respondenti měli uvést číselný odhad (pokud respondenti uváděli rozmezí, byl údaj zprůměrován a zaokrouhlován směrem dolů).

Veškeré kalkulace byly prováděny k hladině významnosti alfa $=0,05$. Síla testu byla vypočítána na 0,81, tedy akceptovatelnou hladinu (Hendl, 2009). Vzhledem k poměrně malému počtu respondentů byly preferovány neparametrické testy, tj. zejména párový Wilcoxonův test. Pro zvýšení spolehlivosti byly některé kalkulace prováděny nezávisle několika testy.

\section{Výsledky}

\section{Četnost návštěv lesa}

Z 61 respondentů, kteří $v$ pretestu odpověděli, kolikrát přibližně byli za poslední měsíc $v$ lese, jich nejvíce (median=15) uvedlo, že jednou, respektive dvakrát. 42 dětí, tedy 60 procent, uvedlo, že bylo $v$ lese maximálně třikrát. $\mathrm{V}$ posttestu došlo $\mathrm{k}$ dílčímu zvýšení deklarovaných hodnot. Pravděpodobným vysvětlením je změna roční doby: 
Tab. č. 1 Četnost návštěv lesa za poslední měsíc

\begin{tabular}{|l|l||l||l||l||l||}
\hline & Počet & Prưměr & Medián & Modus & Četnost modu \\
\hline \hline Návštěv lesa / měsíc před & 61 & 4,4 & 2 & 1,2 & 15 \\
\hline \hline Návštěv lesa / měsíc po & 67 & 5,8 & 3 & 1 & 16 \\
\hline
\end{tabular}

Četnost návštěv lesa $v$ pretestu a v posttestu spolu pozitivně koreluje $(r=0,44)$. Lze proto předpokládat, že chování žáků vytváří relativně stabilní vzorec.

Chlapci uvedli vyšší počet návštěv lesa než dívky. Statistická významnost rozdílu vyšla ale pouze u srovnávání návštěv lesa po programu a při vyhodnocování pomocí WaldWolfowitzova testu (W-W). Srovnání skupin před programem či vyhodnocení pomocí MannWhitneyho testu (M-W) a Kolmogorov-Smirnovova testu (K-S) neprokázalo statistickou významnost rozdílư mezi oběma skupinami. Lze předpokládat, že jedním z důvodů je malá velikost obou skupin, která vnáší do analýzy značnou míru nespolehlivosti.

Tab. č. 2 Porovnání četnosti návštěv lesa před a po programu podle pohlaví

\begin{tabular}{|l|l||l||l|l|l|l||l|l||}
\hline \hline & $\begin{array}{l}\text { Počet } \\
\text { před }\end{array}$ & Počet po & $\begin{array}{l}\text { Průměr } \\
\text { před }\end{array}$ & Průměr po & & $\begin{array}{l}\text { P K-S } \\
\text { test }\end{array}$ & $\begin{array}{l}\text { P M-W } \\
\text { test }\end{array}$ & $\begin{array}{l}\text { P W-W } \\
\text { test }\end{array}$ \\
\hline \hline Chlapci & 25 & 27 & 5,96 & 7,33 & Pred & $>0.1$ & 0,79 & 0.23 \\
\hline \hline Dívky & 36 & 40 & 3,33 & 4,85 & Po & $>0.1$ & 0,94 & $0,03^{*}$ \\
\hline
\end{tabular}

Poznámka: "p" označuje míru pravděpodobnosti náhodného vzniku rozdílů mezi skupinami podle jednotlivých testů, "*" označuje statisticky významné hodnoty.

\section{Strach dětí z lesa}

Hlavní částí dotazníku byl dvaceti položkový test měřící míru strachu respondentů $z$ lesa. $V$ testu byly odpovědi respondentů kódovány na škále 1 (nejmenší strach) až 7 (největší strach). Při dvaceti položkách mohli respondenti získat 20-140 bodů.

Celkově Ize říct, že hodnoty uváděné respondenty odrážejí poměrně malou míru strachu z lesa. Největší strach mají respondenti z divokých zviŕrat, jako jsou divoká prasata, zmije či sršeň, dále pádu stromu či ublížení od cizích osob. Celkový přehled naměřených hodnot je obsažen $v$ príloze č. 1 .

Míra strachu z lesa se po programu mírně snižila. Rozdíl je statisticky významný při kalkulaci pomocí Wilcoxonova párového testu. Při hodnocení pomocí znaménkového testu či párového t-testu nebyl statisticky významný rozdíl naměřen. 
Tab. č. 3 Porovnání míry strachu z lesa pro všechny respondenty před a po programu

\begin{tabular}{|l|l|l|l|l|l||l||}
\hline & Počet & $\begin{array}{l}\text { Průměrný skór } \\
\text { testu }\end{array}$ & SD & Průměrný skór položek & Z & P \\
\hline \hline $\begin{array}{l}\text { Před } \\
\text { programem }\end{array}$ & & 55,6 & 19,3 & 2,75 & & \\
\hline \hline Po programu & 70 & 52,3 & 23,8 & 2,61 & 2,04 & $0,04 *$ \\
\hline
\end{tabular}

Porovnání rozdílu po jednotlivých položkách ukázalo ve třech případech statisticky významný posun směrem ke snížení strachu z lesa:

Tab. č. 4 Položky se statisticky významným rozdílem před a po programu

\begin{tabular}{|l||l|l||l||l||}
\hline Položka & Průměr před & Průměr po & Z & P \\
\hline \hline Ztracení se & 3,22 & 2,68 & 2,31 & $0,02^{*}$ \\
\hline \hline Zastřelení myslivcem & 3,31 & 2,34 & 3,32 & $<0.00^{*}$ \\
\hline \hline Setkání s pytlákem & 3,25 & 2,71 & 2,33 & $0,01^{*}$ \\
\hline
\end{tabular}

Četnost návštěv lesa po programu vyhodnocovaná Spearmanovým testem statisticky významně negativně koreluje $s$ hladinou strachu $z$ lesa uváděnou před programem $(r=-0,33)$. Přestože negativní korelace byla naměřena i pro ostatní kombinace četnosti návštěv lesa a strachu $z$ lesa $v$ obou testech, nebyly naměřené rozdíly statisticky významné. Výpočet Pearsonovým koeficientem ukázal navíc statistickou významnost negativní korelace mezi strachem z lesa po programu a četností návštěv lesa po programu $(r=-0,31)$.

Tab. č. 5 Korelace mezi četností návštěv lesa a strachem z lesa před a po programu

\begin{tabular}{||l||l|l||l|l||}
\hline \multirow{2}{*}{ Proměnná } & \multicolumn{2}{|l|}{$\begin{array}{l}\text { Spearmanovy korelace } \\
\text { Označ. korelace jsou významné na hl. p <,05000 }\end{array}$} \\
\cline { 2 - 5 } & $\begin{array}{l}\text { Návštěvy lesa } \\
\text { před }\end{array}$ & $\begin{array}{l}\text { Strach z lesa } \\
\text { před }\end{array}$ & $\begin{array}{l}\text { Strach z lesa } \\
\text { po }\end{array}$ & $\begin{array}{l}\text { Návštěvy lesa } \\
\text { po }\end{array}$ \\
\hline $\begin{array}{l}\text { Návštěvy lesa } \\
\text { před }\end{array}$ & 1 & $-0,09$ & $-0,05$ & $0,44 *$ \\
\hline $\begin{array}{l}\text { Strach z lesa } \\
\text { před }\end{array}$ & $-0,09$ & 1 & $0,45^{*}$ & $-0,33^{*}$ \\
\hline \hline Strach z lesa po & $-0,05$ & $0,45^{*}$ & 1 & $-0,20$ \\
\hline \hline Návštěvy lesa po & $0,44 *$ & $-0,33^{*}$ & $-0,2$ & 1 \\
\hline
\end{tabular}


Mezi tím, čeho se $v$ lese bojí chlapci a dívky se objevilo několik rozdílů. Celkově Ize říct, že v pretestu i posttestu uváděli chlapci statisticky významně nižší míru strachu než dívky. Kalkulace byla provedena pomocí Kolmogorov-Smirnovova testu:

Tab. č. 6 Porovnání rozdílů v míře strachu z lesa mezi chlapci a dívkami

\begin{tabular}{|c|c|c|c|c|c|c|c|}
\hline & Počet & $\begin{array}{l}\text { Průměrný } \\
\text { skór } \\
\text { testu } \\
\text { před }\end{array}$ & $\begin{array}{l}\text { Průměrný skór } \\
\text { položek před }\end{array}$ & $P$ & $\begin{array}{l}\text { Průměrný } \\
\text { skór testu } \\
\text { po }\end{array}$ & $\begin{array}{l}\text { Průmérný } \\
\text { skór } \\
\text { položek po }\end{array}$ & $P$ \\
\hline Chlapci & 28 & 45,6 & 2,28 & & 47,3 & 2,36 & \\
\hline Dívky & 42 & 62,3 & 3,11 & $<0.25$ & 55,7 & 2,78 & $<0.05^{*}$ \\
\hline
\end{tabular}

Rozdíly se objevily zejména $v$ položkách vyjadřujících obavu z napadení lesní zvěří. Analýza rozdílu mezi pohlavími v pretestu byla provedena pomocí Mann-Whitneyho testu.

Tab. č. 7 Položky z pretestu se statisticky významným rozdílem mezi chlapci a dívkami

\begin{tabular}{|l|l|l|l|l||}
\hline Položka & Dívky průměr & Chlapci průměr & Z & P \\
\hline \hline Divoká zvířata & 3,88 & 2,25 & 3,97 & $<0.00^{*}$ \\
\hline \hline Ztracení se v přírodě & 3,95 & 2,14 & 4 & $<0.00^{*}$ \\
\hline \hline Někdo mi ublíží & 4,5 & 2,35 & 4,14 & $<0.00^{*}$ \\
\hline \hline Divoké prase & 4,54 & 3 & 3,3 & $<0.00^{*}$ \\
\hline \hline Zastřelení myslivcem & 3,76 & 2,64 & 2,03 & $<0.04^{*}$ \\
\hline Pád stromu & 4,23 & 2,5 & 3,5 & $<0.00^{*}$ \\
\hline \hline Setkání s pytlákem & 3,64 & 2,67 & 2,19 & $0,02^{*}$ \\
\hline \hline Bodnutí sršněm & 3,9 & 2,9 & 2,22 & $0,02^{*}$ \\
\hline \hline Zapadnutí do bažiny & 3,97 & 2,85 & 2,27 & $0,02^{*}$ \\
\hline \hline
\end{tabular}

Rozdíly mezi některými položkami ukázala i kalkulace pomocí KolmogorovaSmirnovova testu (divoká zvířata, ztracení se, někdo mi ubliží, divoké prase, pád stromu). Porovnání rozdílů mezi chlapci a dívkami přineslo podobný vzorec. Chlapci vykazují podle Kolmogorova-Smirnovova testu nižší míru strachu v položkách ztracení se v př́rodě, vlk, někdo mi ublíží, divoké prase, zastřelení myslivcem, pád stromu, bodnutí sršněm.

Hodnocení rozdílu mezi pretestem a posttestem odděleně podle pohlaví přineslo výsledky, které jsou patrné už z předešlých tabulek. U dívek $(\mathrm{N}=42)$ došlo ke statistickému snížení míry strachu $z$ lesa $(z=1,95, p=0,05)$. Analýza byla provedena pomocí Wilcoxonova párového testu: 
Tab. č. 8 Položky se statistickým rozdílem mezi pretestem a posttestem u dívek

\begin{tabular}{|l||l|l|l|l||}
\hline Položka & Průměr před & Průměr po & Z & P \\
\hline \hline Ztracení se & 3,95 & 3,33 & 2,51 & $0,01^{*}$ \\
\hline \hline Zastřelení myslivcem & 3,76 & 2,66 & 2,8 & $0,005^{*}$ \\
\hline \hline Zapadnu do bažiny & 3,97 & 3,28 & 2,09 & $0,03 *$ \\
\hline
\end{tabular}

$U$ chlapců $k$ statisticky významné změně $v$ rámci celého testu nedošlo $(z=0,89$, $p=0,36) . K$ posunu došlo u jediné položky:

Tab. č. 9 Položky se statistickým rozdílem mezi pretestem a posttestem u chlapců

\begin{tabular}{|l|l|l||l|l||}
\hline Položka & Průměr před & Průměr po & $Z$ & $P$ \\
\hline \hline Setkání s pytlákem & 2,6 & 1,85 & 2,78 & $0,005^{*}$ \\
\hline
\end{tabular}

Pro jemnější analýzu byly vyhodnoceny rozdíly pro jednotlivé podškály. Rozdíly byly nejprve pro celou skupinu respondentů vyhodnoceny pomocí Wilcoxonova párového testu a znaménkového testu. $V$ podškále "prírodní hrozby" mohli respondenti získat 7 (nejmenší strach) -49 (největší strach) bodů. "Sociální ohrožení zahrnovalo pouze tři položky a respondent tedy mohl získat 3-21 bodů. Nepř́ijemné situace pak osm položek, tedy 8-56 bodů.

Tab. č. 10 Průměrná skóre pro jednotlivé podškály

\begin{tabular}{||l||l|l|l|l||}
\hline Podškála & $\begin{array}{l}\text { Průměrný skór } \\
\text { testu před }\end{array}$ & $\begin{array}{l}\text { Průměrný skór } \\
\text { testu po }\end{array}$ & $\begin{array}{l}\text { Průměrný skór } \\
\text { položek před }\end{array}$ & $\begin{array}{l}\text { Průměrný skór } \\
\text { položek po }\end{array}$ \\
\hline \hline $\begin{array}{l}\text { Př́rodní } \\
\text { hrozby }\end{array}$ & 24,7 & 22,5 & 3,52 & 3,21 \\
\hline \hline $\begin{array}{l}\text { Sociální } \\
\text { ohrožení }\end{array}$ & 10,2 & 8,4 & 3,4 & 2,8 \\
\hline $\begin{array}{l}\text { Nepř́jemné } \\
\text { situace }\end{array}$ & 17,4 & 16,3 & 2,17 & 2,03 \\
\hline
\end{tabular}

Respondenti se nejvíce bojí prírodních hrozeb, tedy zejména rizik spojených s divokou zvěří, a sociálního ohrožení. Nejmenší obavy naopak mají z nepř́ijemných situací $\checkmark$ prírodě. 
Tab. č. 11 Porovnání rozdílů mezi pretestem a posttestem podle jednotlivých podškál

\begin{tabular}{|l||l|l|l|l||l|l||}
\hline Podškála & Průměr před & Průměr po & $Z(W)$ & $P(W)$ & $Z(z)$ & $P(z)$ \\
\hline \hline Přírodní hrozby & 24,7 & 22,5 & 1,76 & 0,07 & 2,12 & $0,03^{*}$ \\
\hline \hline Sociální ohrožení & 10,2 & 8,4 & 2,86 & $0,004 *$ & 1,9 & $0,05^{*}$ \\
\hline \hline Nepř́ijemné situace & 17,4 & 16,3 & 1,8 & 0,07 & 0,99 & 0,32 \\
\hline
\end{tabular}

Pro srovnání rozdílů mezi pohlavími byl použit Kolmogorov-Smirovův test. Je zřejmé, že chlapci a dívky se liší ve vnímání závažnosti přírodních hrozeb a sociálního ohrožení, $a$ to $v$ pretestu i posttestu, zatímco rozdíl $v$ míře obav $z$ nebezpečných situací není ani $\checkmark$ jednom prípadě statisticky významný.

Tab. č. 12 Porovnání rozdílů mezi chlapci a dívkami pro jednotlivé podškály před a po programu

\begin{tabular}{|l||l||l|l|l|l||}
\hline Podškála & Průměr dívky & SD & $\begin{array}{l}\text { Průměr } \\
\text { chlapci }\end{array}$ & SD & P \\
\hline \hline Př́rodní hrozby před & 28,2 & 9,9 & 19,3 & 7,7 & $<0.025^{*}$ \\
\hline \hline Př́rodní hrozby po & 25,3 & 8.1 & 18,4 & 8,1 & $<0.005^{*}$ \\
\hline \hline Sociální ohrožení před & 11,9 & 4,8 & 7,6 & 4,8 & $<0.025^{*}$ \\
\hline \hline Sociální ohrožení po & 9,9 & 3,7 & 6 & 3,6 & $<0.001^{*}$ \\
\hline \hline Nepř́ijemné situace před & 19,2 & 6,4 & 14,8 & 4,9 & $>0.1$ \\
\hline \hline Nepř́íjemné situace po & 16,8 & 5,5 & 15,6 & 5,5 & $<0.1$ \\
\hline
\end{tabular}

Tyto výsledky dále potvrdil Mann-Whitneyho test, který navíc nalezl statistickou významnost $\mathrm{v}$ rozdílu $\mathrm{v}$ obavách $\mathrm{z}$ nepříjemné situace mezi chlapci a dívkami $\mathrm{v}$ pretestu $(z=2,77, p=0,005)$.

Pro vyhodnocení rozdílu mezi pretestem a posttestem podle pohlaví byl použit Wilcoxonův párový test. Nejprve vyhodnotíme výsledky pro dívky: 
Tab. č. 13 Rozdíly mezi pretestem a posttestem podle jednotlivých podškál u dívek

\begin{tabular}{|l||l||l|l|l|l|l||}
\hline \hline Podškála & $\begin{array}{l}\text { Průměrný } \\
\text { skór testu } \\
\text { před }\end{array}$ & $\begin{array}{l}\text { Průměrný } \\
\text { skór testu } \\
\text { po }\end{array}$ & $\begin{array}{l}\text { Průměrný } \\
\text { skór položek } \\
\text { před }\end{array}$ & $\begin{array}{l}\text { Průměrný } \\
\text { skór } \\
\text { položek po }\end{array}$ & Z & P \\
\hline \hline $\begin{array}{l}\text { Př́rodní } \\
\text { hrozby }\end{array}$ & 28,2 & 25,3 & 4 & 3,6 & 1,9 & $0,05^{*}$ \\
\hline \hline $\begin{array}{l}\text { Sociální } \\
\text { ohrožení }\end{array}$ & 11,9 & 9,9 & 3,9 & 3,3 & 2.2 & $0.02 *$ \\
\hline $\begin{array}{l}\text { Nepř́ijemné } \\
\text { situace }\end{array}$ & 19,2 & 16,8 & 2,4 & 2,1 & 3,66 & $<0.000 *$ \\
\hline
\end{tabular}

Znaménkový test potvrdil rozdíl u "prírodních hrozeb" $(z=2,43, p=0,01)$. ohrožení":

U chlapců se statisticky významný posun potvrdil pouze v případě podškály „sociální

Tab. č. 14 Rozdíly mezi pretestem a posttestem podle jednotlivých podškál u chlapců

\begin{tabular}{|l||l|l|l||l|l|l||}
\hline Podškála & $\begin{array}{l}\text { Průměrný } \\
\text { skór testu } \\
\text { před }\end{array}$ & $\begin{array}{l}\text { Průměrný } \\
\text { skór testu } \\
\text { po }\end{array}$ & $\begin{array}{l}\text { Průměrný skór } \\
\text { položek před }\end{array}$ & $\begin{array}{l}\text { Průměrný } \\
\text { skór } \\
\text { položek po }\end{array}$ & Z & P \\
\hline \hline $\begin{array}{l}\text { Př́rodní } \\
\text { hrozby }\end{array}$ & 19,3 & 18,4 & 2,7 & 2,6 & 0,36 & 0,71 \\
\hline $\begin{array}{l}\text { Sociální } \\
\text { ohrožení }\end{array}$ & 7,6 & 6 & 2,5 & 2 & 1,95 & $0,05^{*}$ \\
\hline \hline $\begin{array}{l}\text { Nepř́ijemné } \\
\text { situace }\end{array}$ & 14,5 & 15,6 & 1,8 & 1,9 & 0,16 & 0,87 \\
\hline
\end{tabular}

Znaménkový test v tomto prípadě nepotvrdil žádný statisticky významný rozdíl.

\section{Diskuse}

Výzkum přinesl několik důležitých zjištění. První souvisí s četností návštěv dětí $v$ lese. Podle výsledků chodí děti do lesa poměrně málo, respektive téměř dvě třetiny žáků méně než jednou týdně. Toto zjištění mohlo být ovlivněno malým počtem respondentů a ne zcela štastně zvoleným typem položky (děti měly uvést číselný odhad počtu návštěv lesa za poslední měsíc). Je také zjevné, že výsledky nejsou reprezentativní pro celou populaci. Výzkum dále nezkoumal další faktory, které mohou ovlivňovat četnost návštěv lesa, jako je např́klad vzdálenost domova od lesa či hodnotová orientace žáků a rodičů (Cheng a Monroe, 2012).

Výsledky na druhé straně korespondují s obavami prezentovanými Louvem (2008) i s jinými studiemi. $V$ analýze potřeb $k$ př́pravě nové verze programu Les ve škole - škola 
v lese bylo zjištěno, že z 305 respondentů ve věku 10-11 let, jich 64 procent navštívilo za poslední dva týdny les méně než třikrát, na druhé straně malá skupina dětí (18\%) chodila do lesa téměř každý druhý den (Činčera, 2011).

Souhrnné výsledky nedokládají, že by program přinesl větší efekt na snížení strachu dětí z lesa, přestože jeden z testů prokázal statistickou významnost takové změny. Tyto výsledky ale maskují genderové rozdíly, které jsou pro analýzu přínosů programu zásadní. Podle výzkumu chodí dívky do lesa méně často než chlapci a více se $v$ něm bojí. Přestože zejména porovnání rozdílu $v$ četnosti návštěv lesa není zcela průkazné a mohlo být zkresleno malou velikostí vzorku, koresponduje s výsledky citované předchozí analýzy (Činčera, 2011). Větší strach žen z lesa je doložen i v jiných studiích (Berg a Heijne, 2005; Skårová, 2010). Jestliže chlapci deklarují velmi malou míru strachu již před zahájením programu, je možné, že je program nemohl př́liš ovlivnit, respektive že se dostavil "efekt stropu" (je ale třeba zmínit také možnost, že chlapci v dotazníku svưj strach z lesa nechtějí přiznat). V průběhu programu došlo oproti tomu ke zmírnění strachu z lesa u dívek. Přestože nemáme kontrolní skupinu, zdá se málo pravděpodobné, že by k takovému posunu došlo $v$ průběhu několika měsíců z jiných důvodů. Je proto možné předpokládat, že program na dívky pozitivně zapůsobil a pomohl jim zmírnit část jejich obav z pobytu $\mathrm{v}$ lese.

To, že se chlapci v lese méně bojí, udávají poměrně nízkou hladinu obav a častěji než dívky chodí do lesa, neznamená, že pro ně program nemá smysl. Lze říct, že respondenti celkově chodí do lesa velmi málo. Četnost návštěv lesa je přitom jedním z faktorů rozvíjejících vztah k prírodě a environmentální senzitivitu (Kals, Schumacher a Montada, 1999; Bőgeholz, 2006). Ty přitom patří mezi důležité předpoklady odpovědného environmentálního chování (Chawla, 1997; Chawla a Cushing, 2007). Je možné, že pro zvýšení efektivity je pro chlapce potřeba volit jinou strategii, např́klad posilováním atraktivity aktivit v př́rodě.

Obdobně jako u Andrewse a Gaterslebena (2010) byl strach z lesa pro další analýzu rozdělen do tří podškál. Lze říct, že děti se cítí ohroženy zejména prírodními hrozbami, jako je divoká zvěř či jiná nebezpečí, které mohou vést k vážné újmě na zdraví, a sociálními hrozbami, prezentovanými zlými lidmi či neštastnou nehodou způsobenou myslivcem. Naopak z nepř́jemných situací $v$ lese, jako je ušpinění či ztráta orientace, takový strach nemají. Jestliže se dívky posunuly ve všech sledovaných oblastech, u chlapců došlo k mírnému zmírnění obav pouze u sociálních hrozeb. Celkově byl nejmenší efekt zaznamenán u strachu z nepř́ijemných situací.

To Ize vysvětlit dvěma důvody. Prvním je relativně menší závažnost, kterou respondenti této kategorii ve srovnání s ostatníma dvěma dávali. Druhou pak mưže být charakter intervence, kterou program pro zmírnění tohoto druhu obav nabízel. Můžeme předpokládat, že obavy $v$ kategoriích přírodních hrozeb a sociálního ohrožení jsou do jisté míry syceny mediálními obrazy a ne zcela odpovídají realitě. Je proto možné, že v programu zafungovala "racionalizace" tohoto druhu obav pomocí prezentovaných faktů. Oproti tomu, řešení nepř́jemných situací, jako je například nastydnutí, ztracení se či nedostatek zábavy, mưže souviset s nízkým sebehodnocením vlastní efektivity pro pobyt v přírodě. Lze předpokládat, že takové hodnocení ovlivňuje především vlastní pozitivní zkušenost se zvládnutím určitých situací (Bandura, 1977; Ajzen, 1991). Program sice žáky k řešení takových situací motivuje (jedna z aktivit například motivuje k naplánování a realizaci výletu), je ale možné, že tyto části nejsou ve školní praxi dostatečně implementovány a žáci nemají dost př́ležitostí si potřebné kompetence rozvinout a reflektovat.

Negativní korelace mezi četností návštěv lesa a strachem z lesa je snadno pochopitelná. Lze předpokládat, že když se děti lesa méně bojí, je pro ně les atraktivnější a častěji jej navštěvují. Slabší pozitivní korelaci mezi frekvencí návštěv přírody a pozitivními pocity z lesa dokládá například Berg a Heijne (2005). Na druhé straně nelze ani tuto korelaci přeceňovat. Pocit nebezpečí mưže být pro některé návštěvníky (častěji 
muže) stimulující a může je motivovat k návštěvě „adrenalinové" přírodní lokality (Herzog a Kutzli, 2002).

Nepř́tomnost strachu ještě nezajištuje, že pro děti bude př́roda atraktivní a budou ji rády navštěvovat. Důležitou roli pro zájem dětí o aktivity $v$ prírodě hrají $\mathrm{i}$ další faktory: pocit propojení s prrírodou, předchozí zkušenosti z př́rody, rodinné hodnoty, znalosti či vzdálenost lesa od bydliště lesa (Cheng a Monroe, 2012). Pokud je tedy hlavním cílem programu zvýšit četnost návštěv lesa dětmi, měl by pravděpodobně uplatnit i jiné strategie než jen zmírňování obav. Efektivní by mohlo být např́klad zahrnutí rodičù do programu (Kals, Schumacher a Montada, 1999).

Jak upozorňuje Skårová (2010), stejný les může být vnímán různými návštěvníky jinak, v závislosti na jejich konkrétních zkušenostech. Dưležité je proto motivovat programem $\mathrm{k}$ častým, opakovaným a pozitivním zážitkům $v$ lese $\mathrm{v}$ blízkosti bydliště žáků, a motivovat je tak $k$ jejich volnočasovým návštěvám lokality. Vycházíme-li $z$ teorií - evoluční zakotvenosti obav z určitého typu krajin, mưže být zásadní, spíše než diskutovat o zdrojích obav bez konkrétního zakotvení, učit se překonávat strach a oceňovat krásu konkrétní lokality, která je pro děti dostupná (Herzog a Chernick, 2000; Herzog a Kutzli, 2002; Herzog a Kropscott, 2004; Andrews a Gatersleben, 2010).

Vzhledem $k$ malé velikosti vzorku nelze výsledky výzkumu přeceňovat. Kromě zvýšení velikosti vzorku a zařazení kontrolní skupiny by další zjištění mohlo přinést využití kvalitativních metod, prípadně alternativních postupů na sběr kvantitativních dat.

\section{Literatura}

- Ajzen, I. (1991). The Theory of Planned Behavior. Organizational Behavior and Human Decision Process, 50, 179-211.

- Andrews, M., \& Gatersleben, B. (2010). Variations in perceptions of danger, fear and preference in a simulated natural environment. Journal of Environmental Psychology, 30(4), 473-481. Retrieved from http://linkinghub.elsevier.com/retrieve/pii/S0272494410000460 http://dx.doi.org/10.1016/j.jenvp.2010.04.001

- van den Berg, A. E., \& ter, M., Heijne (2005). Fear versus fascination: An exploration of emotional responses to natural threats. Journal of Environmental Psychology, 25(3), 261272. Retrieved from http://linkinghub.elsevier.com/retrieve/pii/S0272494405000551 http://dx.doi.org/10.1016/j.jenvp.2005.08.004

- Bandura, A. (1977). Self-efficacy: Tpward a Unifying Theory of Behavioral Change. Psychological Review, 84(2), 191-215. Retrieved from http://content.apa.org/journals/rev/84/2/191 pmid:847061 http://dx.doi.org/10.1037/0033295X.84.2.191

- Bogeholz, S. (2006). Nature experience and its importace for environmental knowledge, values and action: recent German empirical contribution.Environmental education research, 12(1), 65-84. Retrieved from http://www.tandfonline.com/doi/abs/10.1080/13504620500526529 http://dx.doi.org/10.1080/13504620500526529

- Činčera, J. (2011). Les ve škole, škola v lese. Evaluační zpráva. Interní dokument. : Praha: Sdružení TEREZA.

- Činčera, J. (2012). Děti a les: analýza mentálních map žáků čtvrtých tříd. Envigogika, 7(1), 10. Retrieved from http://www.envigogika.cuni.cz/index.php/Envigogika/article/view/67 http://dx.doi.org/10.14712/18023061.67

- Danišová, J. (2011). Návrh ročního plánu - 6. tř. ZŠ Program Les ve škole - škola v lese. Pracovní verze. : Praha: Sdružení TEREZA. 
- Emmons, K. M. (2011). Perceptions of the Environment while Exploring the Outdoors: a case study in Belize. Environmental Education Research, 3(3), 327-344. Retrieved from http://www.tandfonline.com/doi/abs/10.1080/1350462970030306 http://dx.doi.org/10.1080/1350462970030306

- Hendl, J. (2009). Přehled statistických metod. Praha: Portál.

- Herzog, T. R., \& Chernick, K. K. (2000). Tranquility and danger in urban and natural settings. Journal of Environmental Psychology, 20(29), 29-39. Retrieved from http://linkinghub.elsevier.com/retrieve/pii/S0272494499901512 http://dx.doi.org/10.1006/jevp.1999.0151

- Herzog, T. R., \& Legibility, K. L. S. (2004). Mystery and Visual Access as Predictors of Preference and Perceived Danger in Forest Settings without Pathways. 2004. Environment and Behavior, 36(4), 659-677. Retrieved http://eab.sagepub.com/cgi/doi/10.1177/0013916504264138 http://dx.doi.org/10.1177/0013916504264138

- Herzog, T. R., \& Kutzli, G. E. (2002). Preference and Perceived Danger in Field/Forest Settings. Environment and Behavior, 34(6), 819-835. Retrieved from http://eab.sagepub.com/cgi/doi/10.1177/001391602237250 http://dx.doi.org/10.1177/001391602237250

- Chawla, L. (1999). Life Paths Into Effective Environmental Action. The Journal of Environmental Education, 31(1), 15-26. Retrieved from http://www.tandfonline.com/doi/abs/10.1080/00958969909598628 http://dx.doi.org/10.1080/00958969909598628

- Chawla, L., \& Cushing, D. F. (2007). Education for strategic environmental behavior. Environmental 'Education Research, 13(4), 437-452. Retrieved from http://www.tandfonline.com/doi/abs/10.1080/13504620701581539 http://dx.doi.org/10.1080/13504620701581539

- J C-h Cheng,, , \& Monroe, M. C. (2012). Connection to Nature: Children's Affective Attitute Toward Nature. Environment and Behavior, 44(1), 31-49. Retrieved from http://eab.sagepub.com/cgi/doi/10.1177/0013916510385082 http://dx.doi.org/10.1177/0013916510385082

- Kals, E., Schumacher, D., \& Montada, L. (1999). Emotional Affinity toward Nature as a Motivational Basis to Protect Nature. Environment and Behavior, 31(2), 178-202. Retrieved from http://eab.sagepub.com/cgi/doi/10.1177/00139169921972056 http://dx.doi.org/10.1177/00139169921972056

- Louv, R. (2008). Last Child in the Woods: Saving Our Children From Nature-Deficit Disorder. Chapel Hill. Chapel Hill, N.C: Algonquin Books.

- Rickinson, M. (2001). Learners and Learning in Environmental Education: a critical review of the evidence. Environmental Education Research, 7(3), 207-320. Retrieved from http://www.tandfonline.com/doi/abs/10.1080/13504620120065230 http://dx.doi.org/10.1080/13504620120065230

- Skår, M. . Forest dear and forest fear: Dwellers' relationships to their neighbourhood forest. Landscape and urban planning, 98, 110-116.

- Stella, M., \& Stibral, K. (2009). „Krajina a evoluce"? Evolučně-psychologické teorie percepce krajiny Envigogika, 4(2), Retrieved from http://www.envigogika.cuni.cz/index.php/Envigogika/article/view/41 http://dx.doi.org/10.14712/18023061.41

PhDr. Jan Činčera, Ph.D. 
Autor vyučuje environmentální výchovu a prožitkovou pedagogiku na Technické univerzitě v Liberci. Jako evaluátor programů dále spolupracuje se středisky ekologické výchovy a organizacemi zabývajícími se globálním rozvojovým vzděláváním.

profesní zaměření: environmentální výchova, vzdělávání pro udržitelný rozvoj, výchova o Zemi, evaluace programů, pedagogika volného času, informační věda

Email: jan.cincera@tul.cz 
Časopis Envigogika vydává Centrum pro otázky životního prostředí UK. Vývoj časopisu je podpořen projektem OP VK Mezioborová sít udržitelného rozvoje.

Více najdete na internetových stránkách projektu http://mosur.czp.cuni.cz
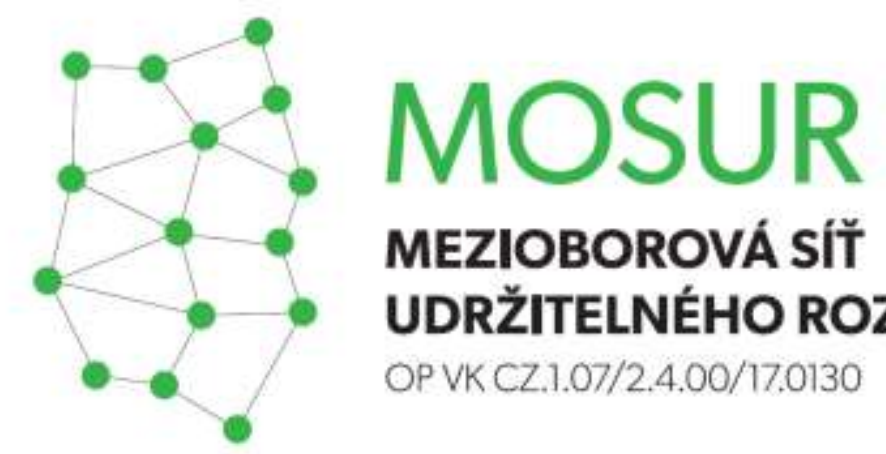

\section{MEZIOBOROVÁ SÍT} UDRŽITELNÉHO ROZVOJE

OP VK CZ.1.07/2.4.00/17.0130
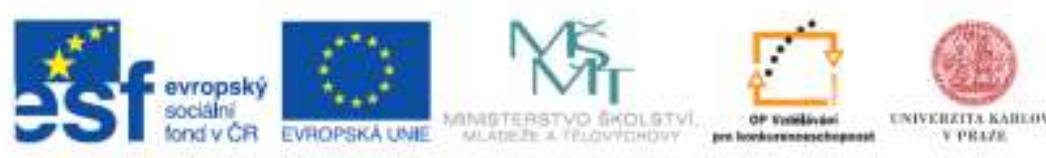

INVESTICE DO ROZVOJE VZDELAVANI 